\title{
IMPLIKASI HUKUM PUTUSAN MAHKAMAH KONSTITUSI NOMOR 16/PUU-X/2012 TERHADAP KEWENANGAN PENYIDIKAN KEJAKSAAN PADA TINDAK PIDANA KORUPSI DALAM PRESPEKTIF SISTEM PERADILAN PIDANA
}

\author{
Sobirin \\ Dwi Nur Fauziah Ahmad \\ Kenashobirin2013@gmail.com \\ Dwi_insiy@yahoo.com
}

Fakultas Hukum Universitas Muhammadiyah Tangerang

\begin{abstract}
ABSTRAK
Penelitian ini dilatar belakangi oleh banyaknya tumpang tindih kewenangan penyidikan kejaksaan terhadap tindak pidana korupsi. Selain itu tidak ada kontrol dan pengawasan cukup kuat dan tegas terhadap kewenangan penyidikan kejaksaan. penelitian ini bertujuan untuk mengetahui implikasi hukum yang ditimbulkan oleh putusan Mahkamah Konstitusi terkait dengan kewenangan kejaksaan terhadap tindak pidana korupsi, serta bagaimana kewenangan penyidikan kejaksaan pada tindak pidana korupsi. Jenis penelitian ini menggunakan pendekatan Normatif-Empiris yang menitikberatkan pada teori kewenangan khususnya terkait kewenangan penyidikan tindak pidana korupsi. Hasil penelitian ini menjelaskan bahwa dalam pasal Undang-Undang Nomor 16 Tahun 2004 Tentang Kejaksaan mengatakan kejaksaan selain memiliki fungsi penuntutan sekaligus memiliki fungsi penyidikan terhadap tindak pidana korupsi. Dalam rumusan pasal Aquo, jelas harus ada undang-undang yang secara tegas memberikan kewenangan kepada kejaksaan. Jika kewenangan tersebut harus berdasarkan Undang-Undang Nomor 31 Tahun 1999 Tentang Tindak Pidana Korupsi sebagaimana diubah dengan Undang-Undang Nomor 20 Tahun 2001 tidak ada satu pasalpun yang tegas memberikan kewenangan kejaksaan sebagai penyidik tindak pidana korupsi. Selain itu dalam pelaksanaannya juga terdapat tumpang tindih kewenangan antara lembaga lain yang mempunyai kewenangan yang sama.

Kata Kunci: Kewenangan, Penyidikan, Kejaksaan, Putusan Mahkamah Konstitusi, Korupsi.
\end{abstract}

\section{ABSTRACT}

This thesis is motivated by the overlapping authority of the prosecutor's investigation of corruption. In addition, there is no control and supervision strong enough and firm on the authority of the prosecutor's investigation. This thesis aims to determine the legal implications of the Constitutional Court's decision related to the authority of the prosecutor's office on corruption, and how the authority to investigate the prosecutor's office on corruption. This type of research uses a Normative-Empirical approach that focuses on the theory of authority, especially related to the authority to investigate criminal acts of corruption. The results of this study explain that in Article Law No. 16 of 2004 concerning the Prosecutor's Office, the prosecutor's office, in addition to having a prosecution function, also has a function of investigating corruption. In the formulation of article Aquo, it is clear that there must be a law that expressly gives authority to the prosecutor's office. If the authority must be based on Law Number 31 Year 1999 Concerning Corruption Acts as amended by Law Number 20 Year 2001, there is no single party that expressly gives the authority of the prosecutor's office as an investigator of criminal acts of corruption. In addition, in the implementation there are also overlapping authorities between other institutions that have the same authority.

Keywords: Authority, Investigations, Prosecutors' Office, Constitutional Court Decision, Corruption. 


\section{Pendahuluan}

Untuk menanggulangi dan memberantas kejahatan korupsi yang bersifat kejahatan luar biasa maka diperlukan pula sinkronisasi atau keterpaduan antara sesama penegak hukum dalam sebuah sistem peradilan pidana yang terbagi menjadi subsistem. Subsistem tersebut yakni antara lain kepolisian, kejaksaan, pengadilan dan lembaga permasyarakatan.

Sejak berlakunya Undang-Undang Nomor 8 tahun 1981Tentang Hukum Acara Pidana (KUHAP) tugas dan kewenangan dalam sistem peradilan pidana diatur secara tegas bagaimana tugas dan kewenangan subsistem untuk menciptakan suatu keterpaduan diantara subsistem tersebut yang lebih dikenal sebagasistem peradilan pidana terpadu (integrated criminal justice system). Dalam kaitannya, tugas antara subsistem dalam sitem peradilan pidana terlihat perbedaan antara tugas dan kewenangannya. Kepolisian sebagai penyidik, kejaksaan sebagai penuntut dan pengadilan sebagai lembaga yang memutuskan perkara. Adanya pemisahan ini menurut Mardjono reksodiputro, tidak boleh mengganggu usaha adanya satu kebijakan penyidikan, penuntutan dan pengadilan yang akan merupakan pedoman kerja bersama dalam proses peradilan pidana. Akan tetapi justeru pemisahan ini sebagai langkah agar proses dalam peradilannya berjalan baik yakni suatu sistem yang menjaga keseimbangan perlindungan kepentingan, baik kepentingan negara, masyarakat dan individu, termasuk kepentingan pelaku tindak pidana dan korban kejahatan. ${ }^{1}$

Begitu juga dengan dalam perkara pidana korupsi, keterpaduan diantara subsistem dalam sistem peradilan pidana sangatlah diperlukan mengingat tindak pidana korupsi merupakan tindak pidana khusus yang bersifat kejahatan luar biasa (ordinary crime) yang diperlukan tindakan khusus juga dalam peradilannya.Berbeda dengan tindak pidana lainnya, dalam tindak pidana korupsi penyidikan tidak hanya dilakukan oleh kepolisian.akan tetapi ada dua institusi lain yang berwenang yakni Kejaksaan dan Komisi Pemberanatasan Korupsi (KPK).

Berdasarkan Undang-Undang Nomor 31 Tahun 1999 sebagaimana diubah dengan Undang-Undang Nomor 20 Tahun 2001 tentang Tindak Pidana Korupsi, Undang-Undang Nomor 16 Tahun 2004 Tentang Kejaksaan Republik Indonesia dan KUHAP, maka kejaksaan mempunyai kewenangan ganda yakniselain sebagai penuntut umum juga mempunyai kewenangan sebagai penyidik dalam pemberantasan tindak pidana korupsi.Dalam KUHAP memang mengatur bahwa kepolisian yang mempunyai kewenangan penyidikan. Pasal 6 KUHAP menyebutkan penyidik adalah Pejabat Polisi Negara Republik Indonesia yang berarti bahwa kepolisian adalah penyidik tunggal. Akan tetapi dalam aturan peralihan peralihan pasal 284 ayat (2) KUHAP menyatakan dalam waktu dua tahun setelah undang-

${ }^{1}$ Sahuri Lasmadi, tumpang Tindih Kewenangan Penyidikan Pada Tindak Pidana Korupsi Dalam Perspektif Sistem Peradilan Pidana, Jurnal Ilmu Hukum, https://onlinejournal.unja.ac.id/jimih/article/view/200/177 hal. 34 
undang ini diundangkan, maka terhadap semua perkara diberlakukan ketentuan undang-undang ini, dengan pengecualian untuk sementara mengenai ketentuan khusus acara pidana sebagaimanatersebut pada undangundang tertentu, sampai ada perubahan dan atau dinyatakan tidak berlaku lagi. ${ }^{2}$

Selanjutnya dalam penjelasan Pasal 284 ayat (2) yang dimaksud "dengan ketentuan khusus acara pidana sebagaimana tersebut pada undangundang tertentu"yaitu mengacu pada ketentuan acara pidana yang menyangkut pengusutan, penuntutan dan peradilan tindak pidana ekonomi (Undang- Undang Nomor 7 Drt Tahun 1955 dan Undang-Undang Nomor 3 Tahun 1971 Tentang Pemberantasan Tindak Pidana Korupsi.sedangkan yang dimaksud dengan " dalam waktu dua tahun setelah undang-undang ini diundangkan" ialah bahwa kewenangan tersebut dibatasi sampai dengan dua tahun sejak KUHAP diundangkan. ${ }^{6}$

Pasal 284 Ayat (2) KUHAP inilah yang menjadi landasan kewenangan Kejaksaan untuk melakukan penyidikan terhadap tindak pidana korupsi. Dalm pasal tersebut sebenarnya adanya pembatasan yang terkandung dalam redaksi "sementara". Namun dalam kenyataannyasetelah sekian banyak ketentuan terkait undang-undang pidana korupsi mulai dari Undang-Undang Nomor 3 Tahun 1971, Undang-Undang Nomor 31 Tahun 1999, sampai dengan Undang-Undang Nomor 20 Tahun 2001 tidak ada penyebutan aturan yang secara tegas terkait apakah Kejaksaan memiliki kewenangan untuku melakukan penyidikan terhadaptindak pidana korupsi. ${ }^{3}$

Ketentuan pasal 26 Undang- Undang Nomor 31 Tahun 1999 dan Pasal 39 Undang-Undang Nomor 30 Tahun 2002 Tentang Pemberantasan Tindak.

Pidana Korupsi dikaburkan oleh Pasal 50 Ayat (1), (2), (3) dan (4) Undang- Undang Nomor 30 Tentang Komisi pemberantasan Korupsi). Dengan permasalahan diatas menjadikan kontradiksi terkait kewenangan jaksa dalam menyidik kasus korupsi dimana dalam UU aquo tidak memberikan kewenangan yang tegas kepada kejaksaan sebagai penyidk korupsi.

Dengan kewenangan ganda tersebut maka peranannya dalam tindak pidana korupsi sangatlah dominan. Hal ini menjadikan kewenangan ganda tersebut rawan diselewengkan atau disalahgunakan karena tidak adanya kontrol dalam menjalankan kedua kewenangan, selain jaksa sebagai penyidik terhadap tindak korupsi, jaksa tetap menjalankan fungsi sebagai penuntut umum.

KUHAP secara eksplisit memberi pengertian bahwa penuntutan adalah proses tahapan selanjutnya setelah proses penyidikan. Dalam hal ini

\footnotetext{
${ }^{2}$ Sahuri Lasmadi, Analisis Yuridis Kewenangan Kejaksaan Dalam Melakukan Penyidikan Tindak Pidana Korupsi, Jurnal Ilmu Hukum, http://repository.unja.ac.id/597

/1/2.\%20Tulisan\%20Sahuri\%20L.pdf, Volume 6 No.2, 2015, hal 12

3 Martuaful Latifah, Legalitas Kewenangan Jaksa Dalam Penyidikan Tindak Pidana Korupsi,JurnalNegara Hukum,https://jurnal.dpr.go.id/index.php/hukum/article /view/226/ 167 vol. 3 No. 1, 2012 hal 105
} 
bahwa setelah penyidikan selesai dan berkas masuk dalam tahap pelimpahan, maka diperlukan pengecekan kembali berkas tersebut dalam tahapan pra penuntutan dimana penuntut umum melakukan tindakan untuk memberikan petunjuk dalam rangka penyempurnaan penyidikan oleh penyidik. Beberapa kalangan menilai bagaimana jika peran penyidik dan penunutut umum dalam satu lingkup satu instansi, maka penyidikan dikoreksi sendiri oleh penuntut umum yang notabene juga merupakan penyidik.

Sebagai contoh dalam kasus tindak pidana korupsi dengan terdakwa mantan Gubernur Bali yakni Ida Bagus Oka terkait kasus korupsi penjualan stiker wajib bagi pembayar pajak untuk kegiatan olahraga disidik sekaligus dituntut oleh Jaksa Tri Urip Gunawan. Menurut OC. Kaligis, dengan fakta tersebut, maka jaksa bisa seenaknya menentukan sebuah kasus korupsi. Bahkan kemungkinan kasus- kasus korupsi hanya dimanfaatkan pihak kejaksaan. Kaligis menyatakan kewenangan penyidikan hendaknya dilimpahkan ke kepolisian. Jika penyidikan dan penuntutan dilakukan pemisahan antara penegak hukum maka akan memunculkan kontrol kinerja penegak hukum. ${ }^{4}$

Dengan adanya permasalahan diatas, kemudian ada beberapa kalangan yang menilai bahwa persoalan tersebut menimbulkan tidak hanya sengketa kewenangan antara lembaga negara akan tetapi juga menimbulkan "ketidakpastian hukum" bagi para pihakyang bersengketa didalamnya. Dan hal ini tentunya bertentangan dengan amanah UUD NRI 1945 sebagaimana yang tertuang dalam Pasal 28D Ayat (1) yang secara tegas menyatakan bahwa: "setiap orang berhak atas pengakuan, jaminan, perlindungan dan kepastian hukum yang adil serta perlakuan yang sama dihadapan hukum."

Atas dasar tersebut diatas serta mengingat salah satu kewenangan Mahkamah Konstitusi untuk menguji suatu undang- undang terhadap UUD NRI 1945 maka diajukanlah permohonan untuk dilakukan pengujian suatu undang-undang (judicial review) terhadap Pasal 30 Ayat (1) UndangUndang Nomor 16 Tahun 2004 Tentang Kejaksaan Republik Indonesia, Pasal 39 Undang-Undang Nomor 31 Tahun 1999 Tentang Pemberantasan Tindak Pidana Korupsi dan Pasal 44 Ayat (4) dan Ayat (5), Pasal 50 ayat (1), ayat (2), ayat (3) dan ayat (4) Undang-Undang Nomor 30 Tahun 2002 Tentang Komisi Pemberantasan Korupsi (KPK). Undang- undang tersebut telah menimbulakan ketidakpastian hukum. Hasil pengujian ini kemudian dituangkan dalam amar putusan dengan Nomor 16/PUU-X/2012.

Dalam amar putusannya Majelis Hakim menolak permohonan para pemohon untuk seluruhnya dengan alasan bahwa Presiden mempunyai kewenangan selain sebagai pemegang kekuasaan pemerintahan (eksekutif), juga berfungsi sebagai pembentuk Undang-Undang (legislatif) bersama dengan Dewan Perwakilan Rakyat. Dengan demikian Undang-Undang Dasar Negara Republik Indonesia 1945 tidak melarang fungsi ganda tersebut. Sehingga begitupun dengan dengan kewenangan ganda Kejaksaan

4 O.C.Kaligis, Pengawasan Terhadap Jaksa Selaku Penyidik Tindak Pidana Khusus dalam Pemberantasan Korupsi, (P.T. Alumni Bandung, 2006) hal 121. 
selain melakukan penuntutan, juga berfungsi bisa melakukan penyidikan terhadap tidak pidana korupsi.

Berdasarkan uaraian identifikasi masalah diatas, maka yang menjadi pokok kajian sebagai permasalahan bagaimana kewenangan kejaksaan dalam melakukan penyidikan tindak pidana korupsi dan bagaimana implikasi putusan MK Nomor 16/PUU-X/2012 terhadap kewenangan penyidikan kejaksaan pada tindak pidana korupsi dalam prespektif sistem peradilan pidana.

Tujuan dari penelitian ini adalah sebagai untuk mengetahui legalitas kewenangan kejaksaan dalam melakukan penyidikan tindak pidana korupsi dan untuk mengetahui implikasi hukum Putusan MK Nomor 16?PUU$\mathrm{X} / 2012$ terhadap kewenangan penyidikan Kejaksaan pada tindak pidana korupsi dalam prespektif sistem peradilan pidana.

\section{Metode Penelitian}

Jenis penelitian dalam penulisan artikel ini adalah menggunakan jenis penelitian normatif empiris untuk mendeskripsikan segala hal yang berkaitan dengan rumusan masalah dan pokok permasalahan. Dalam hal ini yang berkaitan dengan kewenangan kejaksaan dalam penyidikan kasus korupsi.

Sumber data terdiri dari data primer adalah data yang diperoleh peneliti secara langsung. Data primer yang digunakan dalam penulisan proposal ini adalah Undang-Undang Nomor 16 Tahun 2004 Tentang Kejaksaan Republik Indonesia, Undang-Undang Nomor 31 tahun 1999 Tentang pemberantasan tindak Pidana Korupsi sebagaimana diubah dengan Undang-Undang No. 20 Tahun 2001 dan KUHAP serta Putusan MK Nomor 16/PUU-X/2012. Sedangkan data sekunder adalah data yang diperoleh peneliti dari sumber yang ada seperti bahan hukum primer, bahan hukum sekunder, bahan hukum tersier

\section{Hasil Penelitian Dan Analisis}

\section{Pelaksanaan kewenangan Jaksa sebagai Penyidik Kejaksaan Negeri Kota Tangerang terhadap Tindak Pidana Korupsi}

Peran jaksa sebagai penyidik dalam penanganan kasus tindak pidana korupsi diatur dalam KUHAP dan Undang-Undang Nomor 16Tahun 2004 tentang Kejaksaan Republik Indonesia, dengan tahap penyelidikan, penyidikan dan penuntutan. Jaksa sebagai penyidik dalam penanganan tindak pidana korupsi berpegang pada Doktrin Kejaksaan TRYKRAMA ADHYAKSA yaitu Satya (Kesetiaan), Adhy (kesempurnaan), Wicaksana(kebijaksanaan), sebagai pedoman yang menjiwai setiap warga Kejaksaan agar mampu memperkokoh pengenalan dan pemahamannya 
(orientasi) akan makna amanah serta tugas-tugas yang dipercayakan olehnegara.Kejaksaan dalammenjalankan tugas-tugas negara tetap berpegang dan sesuai dengan doktrin kejaksaan. ${ }^{5}$

Jaksa mempunyai wewenang dalam menyidik tindak pidana. Karena tugas-tugas penyidikan sepenuhnya dilimpahkan pada pejabat penyidik, maka jaksa tidak lagi berwenang dalam melakukan penyidikan terhadap perkara-perkara tindak pidana umum. Jaksa hanya berwenang untuk melakukan penyidikan terhadap tindak pidana khusus, yang salah satunya adalah tindak pidana korupsi.

Mekanisme pelaksanaan kewenangan kejaksaan dalam penanganan tindak pidana korupsi mekanisme pemeriksaan tindak pidana korupsi dalam hal ini kejaksaan Negeri Kota Tangerang menggunakan hukum acara yang berlaku yakni KUHAP. Dalam penanganannya tindak pidana korupsi kejaksaan mempunyai bagian yang terdiri dari bagian penyidikan pidana khusus dan penuntutan pidana khusus. Bidang penyidikan di kepalai oleh kepala seksi bidang penyidikan sedangkan penuntutan dikepalai oleh kepala seksi bidang penuntutan.

Secara aturan administratif dan aturan KUHAP bahwa Kedua bagian harus terpisah untuk menghindari kesewenangan atau penyalahgunaan wewenang jaksa. Akan tetapi dalam kenyataannya di kejaksaan Negeri Kota Tangerang bahwa seorang jaksa dapat menjadi penyidik sekaligus dapat sebagai penuntut dengan dalih memakai aturan Keputusan Jaksa Agung Republik Indonesia Nomor: KEP-518/A/J.A/11/2001 Tentang Perubahan Keputusan Jaksa Agung Republik Indonesia Nomor: KEP- 132/J.A/11/1994 Tentang Administrasi Perkara Pidana. ${ }^{6}$

Adapun mekanisme tindak pidana korupsi sebagai berikut seeperti pemeriksaan awal atau pendahuluan proses pemeriksaan pendahuluan ini berupa kegiatan yang rincinya merupakan pemeriksaan persiapan, yaitu tindakan penyelidikan dan penyidikan. Penyelidikan merupakan tindakan awal pemeriksaan perkara dan pembatasan lainnya dari tugas penyidikan. Pasal 1 butir 2 KUHAP menentukan bahwa penyidikan adalah serangkaian tindakan penyidik dalam hal dan menurut cara-cara yang diatur dalam undang-undang untuk mencari serta mengumpulkan bukti, dan dengan bukti itu membuat terang tindak pidana yang terjadi dan menemukan tersangka. Untuk menunjang dan mempermudah kegiatan penyidikan biasanya jaksa melakukan penahanan terhadap tersangka atau terdakwa yang tata caranya diatur oleh aturan KUHAP.

Penuntutan dalam hal penuntutan ini Jaksa melakukan atau membuat surat dakwaan. Surat Dakwaan adalah surat yang dibuat atau disiapkan oleh Penuntut Umum yang dilampirkan pada waktu melimpahkan berkas perkara ke Pengadilan yang memuat nama dan identitas pelaku perbuatan pidana,

${ }^{5}$ Kelik Pramudya dan Ananto Widianto, Pedoman EtikaProfesi Aparat Hukum, Pustaka Yustisia, Yogyakarta, 2010,hal.. 44

${ }^{6}$ Hasil wawancara dengan Reza Pahlevi Kasubsi Penuntutan Tindak Pidana Khusus Kejaksaan Negeri Kota Tangerang pada tanggal 21 Agustus 2019. 
kapan dan dimana perbuatan dilakukan serta uraian secara cermat, jelas dan lengkap mengenai perbuatan tersebut yang didakwakan telah dilakukan oleh terdakwa yang memenuhi unsur-unsur pasal- pasal tertentu dari undangundang tang tertentu pula yang nantinya merupakan dasar dan titik tolak pemeriksaan terdakwa di Sidang Pengadilan untuk dibuktikan apakah benar perbuatan yang didakwakan itu betul dilakukan dan apakah betul terdakwa adalah pelakunya yang dapat dipertanggungjawabkan untuk perbuatan tersebut.

Dalam pelaksanaannya menurut hasil keterangan Kejaksaan Negeri Kota Tangerang mengatakan bahwa Kejaksaan merupakan pihak yangbertanggung jawab terhadap proses dari awal, sampai di hadapan peradilandiberikan kewenangan yang sama, karena Kejaksaan yang melakukan pengawasanterhadap penyidikan dan penyelidikan yang dilakukan oleh polisi. Hal tersebutkemudian menegaskan bahwa sistem peradilan pidanamerupakan sistemyang memandang proses penyelesaian perkara pidana sebagai satu rangkaiankesatuan sejak penyidikan, penuntutan, pemutusan perkara, hingga penyelesaian di tingkat lembaga pemasyarakatan. Jadi, bukan sistem yang akan menjurus pada pemisahan fungsi yang dapat mengakibatkan sulit dan lambatnyapenyelesaian masalah yang ada. ${ }^{7}$

Lebih lanjut hal itulah menurut hasil wawancara kejaksaan ada keistimewaan tersendiri bahwa kejaksaan mempunyai kewenangan penyidikan sekaligus penuntutan tanpa ada petunjuk pra penuntutan. Meskipun secara administratif bahwa kewenangan penyidikan dan kewenangan terpisah, yakni kewenangan penyidik di bawah tanggung jawab kepala seksi bagian penyidikan sedangkan kewenangan penuntut ada di bawah tanggung jawab kepala seksi bagian penuntutan, akan tetapi dalam pelaksanaannya penyidik bisa menjadi sekaligus penuntut.

Faktor Kendala dalam Pelaksanaan Penyidikan Tindak Pidana Korupsi dari hasil penelitian penulis yang diperoleh dari kejaksaan Negeri Kota Tangerang dalam menanani kasus korupsi ada beberapa kendala yang dihadapi antara lain. ${ }^{8}$

Adanya tumpang tindih kewenangan dalam penangana kasus korupsi masih terdapat tumpang tindih kewenangan antar penegak hukum (kepolisian, kejaksaan dan kepolisian).dalam menangani tindakpidana korupsi. Dalam hal ini tidak adanya sinergi dan kerjasama yang baik antara kepolisian, kejaksaan dan KPK yang notabene mempunyai kewenangan melakukan penyidikan kasus korupsi.

Adanya kompleksitas permasalahan korupsi kompleksitas dalam proses penegakkan hukum terhadap tindak pidana korupsi menjadi kendala dalam rangka upaya pemberantasan korupsi itu sendiri, oleh karena itu

\footnotetext{
7 Hasil wawancara dengan Reza Pahlevi Kasubsi Penuntutan Tindak Pidana Khusus Kejaksaan Negeri Kota Tangerang pada tanggaL 19 Agustus 2019

8 Hasil wawancara dengan Reza Pahlevi Kasubsi Penuntutan Tindak Pidana Khusus Kejaksaan Negeri Kota Tangerang pada tanggal 21 Agustus 2019
} 
proses penegakkan hukun tersebut membutuhkan waktu yang cukup panjang.

Pengembalian aset kerugian negara arah penerapan hukum dan moralitas penegak hukum dalam proses penegakkan hukum terhadap tindak pidana korupsi salah satunya adalah menyelamatkan keuangan Negara. Dalam kenyataan yang terjadi sering kali harta koruptor yang semestinya harus dikembalikan negara itu tidak bisa dikembalikan lantaran sudah habis sebelumnya.

Selanjutnya menurut keterangan Kejaksaan Negeri Kota Tangerang dengan adanya tumpang tindih kewenangan antara penegak hukun antara kepolisian, kejaksaan dan KPk sehingga Pada tahun 2017 ketiga institusi tersebut membuat nota kesepahaman (MOU) dalam penanganan korupsi. MOU tersebut merupakan pembaharuan dari Nota Kesepahaman sebelumnya dan dianggap sebagai bentuk penyempurnaan. Maksud dan tujuan nota kesepahaman ini adalah sebagai pedoman bagi para pihak dalam rangka pemberantasan tindak pidana korupsi dan untuk meningkatkan sinergitas kerjasama dan koordinasi antara ketiga instansi tersebut. ${ }^{9}$

Lebih lanjut menurut keterangannya juga nota kesepahaman ini ada beberapa ruang lingkup diantaranya sinergi penanganan tindak pidana korupsi, pembinaan aparatur penegak hukum, bantuan narasumber/ahli, pengamanan sarana dan prasarana, permintaan data dan informasi dan peningkatan dan pengembangan kapasitas kelembagaan serta sumber daya manusia.

\section{Analisis Kewenangan Kejaksaan Dalam Melakukan Penyidikan Tindak Pidana Korupsi}

Sejalan dengan pilar utama negara hukum yaitu asas legalitas, atas dasar prinsip tersebut bahwa wewenang pemerintahan berasal dari peraturan perundang-undangan yang berlaku oleh karenanya menurut Philipus M. Hadjon kewenangan dibagi menjadi dua cara yaitu dengan atribusi dan pelimpahan wewenang.

Atribusi adalah wewenang yang melekat pada suatu jabatan. Kewenangan yang dimiliki oleh organ pemerintahan dalam menjalankan pemerintahannya berdasarkan kewenangan yang dibuat oleh pembuat undang-undang. Atribusi menunjuk bahwa kewenangan ini lahir dari amanat konstitusi atau peraturan perundang-undangan.

Pelimpahan wewenang adalah penyerahan sebagian dari wewenang pejabat atasan kepada bawahan tersebut membantu dalam melaksanakan tugas-tugas dan kewajibannya untuk bertindak sendiri.

delegasi adalah wewenang yang bersumber dari pelimpahan suatu organ pemerintahan kepada organ lain dasar peraturan perundang-undangan.

Mandate adalah wewenang yang bersumber dari prosesatau prosedur

9 Hasil wawancara dengan Reza Pahlevi Kasubsi Penuntutan Tindak Pidana Khusus Kejaksaan Negeri Kota Tangerang pada tanggal 19 Agustus 2019 
pelimpahan dari pejabat atau badan yang lebih tinggikepada pejabat yang lebih rendah.

Stuktur organ kejaksaan berpusat pada Kejaksaan Agung. Kejaksaan Agung secara eksplisit tidak diatur dalam Konstitusi (UUD 1945), akan tetapi dalam kaitannya kejaksaan dibentuk berdasarkan Undang-Undang. Undang-Undang yang mengatur kejaksaan adalah Undang-Undang Nomor 5 Tahun 1991 Tentang Kejaksaan. Pada tahun 2004 Undang- Undang tersebut digantikan oleh Undang-Undang baru, yakni Undang-Undang Nomor 16 Tahun 2004 Tentang Kejaksaan. Dalam Undang-Undang terkhir ini, ditentukan bahwa jaksa adalah pejabat fungsional yang diberi wewenang oleh Undang-Undang untuk bertindak sebagai penuntut umum dan pelaksana pengadilan yang telah memperoleh kekuatan hukum tetap serta wewenang lain yang diberikan Undang-Undang.

Kejaksaan Republik Indonesia adalah lembaga pemerintah yang melaksanakan kekuasaan negara dibidang penuntutan serta kewenangan lain berdasarkan undang-undang. Kejaksaan sebagai lembaga pemerintah terdiri atas Kejaksaan Agung, Kejaksaan Tinggi dan Kejaksaan Negeri. Kejaksaan agung berkedudukan di ibukota negara dan daerah hukumnya meliputi seluruh wilayah kekuasaaan negara Republik Indonesia. Kejaksaan dipimpin oleh jaksa agung yang mengendalikanpelaksanaan dan wewenang kejaksaan. Dalam melaksanakan tugas dan wewenangnya jaksa agung dibantu oleh seorang wakil jaksa agung dan beberapa jaksa agung muda. Wakil jaksa agung dan jaksa agung muda diangkat dan diberhentikan oleh presiden atas usul jaksa agung.

Sistem peradilan pidana di Indonesia sangatlah berperan sekali dalam rangka penegakan hukum terutama pada tindak pidana korupsi, agar kepastian hukum dapat tercapai, karena didalam sistem peradilan terkandung gerak sistematis dari subsistem-subsistem pendukung antara Kepolisian, Kejaksaan, Pengadilan dan Lembaga Pemasyarakatan) yang secara keseluruhan dan merupakan satu kesatuan Untuk itu perlu adanya kepastian hukum tentang kewenangan masing-masing subsistem-subsistem dalam system peradilan pidana terutama dalam penyidikan pada tindak pidana korupsi. Jika keterpaduan kewenangan masing-masing subsistemsubsistem dalam sistem peradilan pidana tidak terwujud, masyarakat dapat beranggapan bahwa sistem peradilan pidana menyebabkan timbulnya kejahatan apalagi tindak pidana korupsi.

Sejak berlakunya Undang-Undang Nomor 8 Tahun 1981 tentang Hukum Acara Pidana, Undang-Undang Nomor 14 Tahun 1970 jo UndangUndang Nomor 35 Tahun 1999 jo Undang-Undang Nomor 4 Tahun 2004 tentang Ketentuan Pokok Kekuasaan Kehakiman, Undang-Undang Nomor 16 Tahun 2004 tentang Kejaksaan Republik Indonesia dan Undang-Undang Nomor 2 Tahun 2002 tentang Kepolisian Negara Republik Indonesia, maka baik hakim, jaksa dan polisi diatur secara terpisah dan mandiri, yang tentunya berdampak pada pelaksanaan penegakan hukum, yaitu terjadinya tumpang tindih tugas, kewenangan dan tanggung jawab antara polisi, jaksa dan hakim, bahkan terdapat kesan koordinasi fungsional dalam sistim 
peradilan pidana terpadu (intergrated Judiciary System) tidak berjalan sebagaimana yang diharapkan.

Berdasarkan Undang-Undang Nomor 31 Tahun 1999 sebagaimana diubah dengan Undang-Undang Nomor 20 Tahun 2001 tentang Tindak Pidana Korupsi, Undang-Undang Nomor 16 Tahun 2004 Tentang Kejaksaan Republik Indonesia dan KUHAP, maka kejaksaan mempunyai kewenangan ganda yakniselain sebagai penuntut umum juga mempunyai kewenangan sebagai penyidik dalam pemberantasan tindak pidana korupsi. Dalam KUHAP memang mengatur bahwa kepolisian yang mempunyai kewenangan penyidikan. Pasal 6 KUHAP menyebutkan penyidik adalah Pejabat Polisi Negara Republik Indonesia yang berarti bahwa kepolisian adalah penyidik tunggal. Akan tetapi dalam aturan peralihan peralihan pasal 284 ayat (2) KUHAP menyatakan dalam waktu dua tahun setelah undangundang ini diundangkan, maka terhadap semua perkara diberlakukan ketentuan undang-undang ini, dengan pengecualian untuk sementara mengenai ketentuan khusus acara pidana sebagaimana tersebut pada berlaku lagi.

Selanjutnya dalam penjelasan Pasal 284 ayat (2) yang dimaksud "dengan ketentuan khusus acara pidana sebagaimana tersebut pada undangundang tertentu" yaitu mengacu pada ketentuan acara pidana yang menyangkut pengusutan, penuntutan dan peradilan tindak pidana ekonomi (Undang- Undang Nomor 7 Drt Tahun 1955 dan Undang-Undang Nomor 3 Tahun 1971 Tentang Pemberantasan Tindak Pidana Korupsi.sedangkan yang dimaksud dengan " dalam waktu dua tahun setelah undang-undang ini diundangkan" ialah bahwa kewenangan tersebut dibatasi sampai dengan dua tahun sejak KUHAP diundangkan.

Pasal 284 Ayat (2) KUHAP inilah yang menjadi landasan kewenangan Kejaksaan untuk melakukan penyidikan terhadap tindak pidana korupsi. Dalam pasal tersebut sebenarnya adanya pembatasan yang terkandung dalam redaksi "sementara". Namun dalam kenyataannyasetelah sekian banyak ketentuan terkait undang-undang pidana korupsi mulai dari Undang-Undang Nomor 3 Tahun 1971, Undang-Undang Nomor 31 Tahun 1999, sampai dengan Undang-Undang Nomor 20 Tahun 2001 tidak ada penyebutan aturan yang secara tegas terkait apakah Kejaksaan memiliki kewenangan untuku melakukan penyidikan terhadaptindak pidana korupsi.

Dengan adanya redaksi sementara itulah menimbulkan banyak penafsiran tentang apakah Kejaksaan memiliki kewenangan untuk melakukan penyidikan terhadap tindak pidana korupsi.

Menurut analisa penulis semula kewenangan tersebut hanya dipertahankan dalam waktu dua tahun atau sampai ada pergantian undangundang khusus seperti undang-undang korupsi dan undang-undang tindak pidana ekonomi. Artinya bahwa kewenangan kejaksaan untuk melakukan penyidikan terhadap tindak pidana korupsi telah habis masa berlakunya. Kewenangan tersebut diberikan hanya samapai undang- undang terkait dengan tindak pidana korupsi dan undang-undang tindak pidana ekonomi diperbarui dan posisi kejaksaan dikembalikan sebagai pengawas terhadap 
penyidikan yang dilakukan oleh kepolisian sesuai sistem peradilan pidana yang diatur oleh KUHAP.

Selain itu dengan kewenangan ganda tersebut maka peranannya dalam tindak pidana korupsi sangatlah dominan. Hal ini menjadikan kewenangan ganda tersebut rawan diselewengkan atau disalahgunakan karena tidak adanya kontrol dalam menjalankan kedua kewenangan, selain jaksa sebagai penyidik terhadap tindak korupsi, jaksa tetap menjalankan fungsi sebagai penuntut umum.

Persoalan yang muncul apakah tidak menimbulkan tumpang tindih di antara para Jaksa yang melakukan penyidikan juga melakukan penuntutan, Jika wewenang Jaksa selaku penyidik (tindak pidana korupsi) terus dipertahankan, bukankah hal tersebut justru mengacaukan pelaksanaan penyidikan-penuntutan menurut aturan KUHAP? Tidak adanya kontrol terhadap Jaksa selaku penyidik, telah menghasilkan berbagai pelanggaranpelanggaran serius terhadap KUHAP; misalnya Pelanggaran terhadap Pasal 109 ayat (1) KUHAP dalam keadaan umum, penyidik harus melaporkan kepada penuntut umum tentang saat dimulainya penyidikan suatu perkara. Apabila penyidik tersebut berasal dari instansi yang sama dengan penuntut umum, maka penyidik tidak pernah dan merasa tidak perlu memberitahukan kepada penuntut umum pada saat dimulainya penyidikan. Dalam perkara tindak pidana korupsi, sering penyidik berasal dari Kejaksaan Agung, dari segi kepangkatan, senioritas dan pengalaman, lebih tinggi dari penuntut umum yang berada di Kejaksaan Negeri. Sehingga Jaksa penyidik tidak merasa perlu untuk memberitahukan kepada penuntut umum, yang berpangkat lebih rendah, saat dimulainya penyidikan yang dilakukannya. Kalaupun ada pemberitahuan, maka Jaksa yang pangkatnya lebih rendah tidak mungkin mengontrol sesuai dengan legal culture kita di mana berlaku budaya petunjuk.

Pelanggaran Pasal 110 KUHAP yakni keharusan penuntut umum untuk menerima berkas perkara dari hasil penyidikan, untuk dipelajari dan ditentukan apakah hasil penyidikan sudah lengkap atau belum. Apabila penyidik dan penuntut umum berada pada satu instansi yang sama (satu atap), maka tidak pernah terjadi, penuntut umum memberikan "formulir P18 atau P-19 (berkas penyidikan dikembalikan disertai catatan-catatan) kepada penyidik. Apalagi jika penyidik memiliki pangkat yang lebih tinggi dari penuntut umum, maka apapun bentuk hasil penyidikan tersebut, penuntut umum akan segera wajib meneruskan perkara tersebut dan tidak mungkin menyatakan bahwa berkas perkara tersebut tidak/belum lengkap.Dalam perkara tindak pidana korupsi atas nama Kaharudin Ongko, salah seorang Komisaris Bank Umum Nasional yang ditutup pemerintah, tampak jelas bagaimana proses penerapan Pasal 109 maupun Pasal 110 KUHAP dilanggar begitu saja. Penyidik dalam kasus ini adalah seorang Jaksa madya. Sama halnya dalam perkara pidana korupsi Ida Bagus Oka di Pengadilan Denpasar, yang penyidik dan penuntut umumnya adalah Jaksa Urip Tri Gunawan. Dalam kedua kasus tersebut, Jaksa penyidiknya, Arnold Angkow dan Urip Tri Gunawan, juga sekaligus menjadi penuntut umum. 
Artinya, penyidik dan penuntut umum berada pada wewenang 1 (satu) pejabat yang sama.

Pelanggaran Pasal 1 angka (24) jo. Pasal 7 ayat (1) point (a) jo. Pasal 14 KUHAP, di mana seorang Jaksa bertindak sebagai saksi pelapor, kemudian Jaksa yang sama bertindak juga sebagai penyidik, dan kemudian bertindak lagi sebagai penuntut umum. Dalam Pasal 30 Ayat (1) huruf (d) UU Kejaksaan, merupakan salah satu sumber dalam pendelegasian kewenangan jaksa dalam melakukan penyidikan tindak pidana korupsi. Hasil dari keterangan kementerian Hukum dan HAM beranggapan bahwa ketentuan tersebut berpotensi menimbulkan ketidak-pastian hukum karena kewenangan penyidikan tindak pidana korupsi diletakkan dalam Penjelasan bukan di dalam norma. Jadi kewenangan penyidikan tindak pidana korupsi tidak mempunyai kekuatan mengikat karena diletakkan dalam penjelasan bukan di dalam norma.

Penulis beranggapan yakni berdasarkan UU No. 12 Tahun 2011 tentang Pembentukan Peraturan Perundang-undangan (UU P3), Fungsi dan peran penjelasan suatu peraturan perundang-undangan sudah diatur dalam Lampiran I UU P3, antara lain dalam angka-angka 176, 177 dan 186. Dalam ketentuan lampiran I angka 176 disebutkan bahwa "Penjelasan berfungsi sebagai tafsir resmi pembentuk Peraturan Perundang-Undangan atas norma tertentu dalam batang tubuh. Oleh karena itu, penjelasan hanya memuat uraian terhadap kata, frasa, kalimat atau padanan kata/ istilah asing dalam norma yang dapat disertai dengan contoh. Penjelasan sebagai sarana untuk memperjelas norma dalam batang tubuh tidak boleh mengakibatkan terjadinya ketidakjelasan dari norma yang dimaksud". Selanjutnya dalam angka 177, dinyatakan bahwa "Penjelasan tidak dapat digunakan sebagai dasar hukum untuk membuat peraturan lebih lanjut dan tidak boleh mencantumkan rumusan yang berisi norma". Hal ini berkaitan dengan lampiran I angka 186 huruf b yang menyatakan bahwa dalam pembentukan penjelasan, Rumusan penjelasan pasal demi pasal "tidak memperluas, mempersempit atau menambah pengertian norma yang ada dalam batang tubuh.

Lain halnya dengan hasil penelitian penulisan yang diperoleh dari Kejaksaan Negeri Kota Tangerang yang mengatakan bahwa penjelasan dalam pasal 30 Ayat (1) huruf d mengikat. Pihak kejaksaan beralasan penjelasan merupakan satu kesatuan dangan norma dengan pasal tersebut. Pihak kejaksaaan beranggapan bahwa dalam mengartikan sebuah pasal tidak boleh menafsirkan secara parsial. kesimpulan yang diperoleh menyatakan bahwa penjelasan harus melekat dengan norma tanpa harus terpisah dalam mengartikan sebuah pasal atau norma tersebut. 


\section{Implikasi Putusan Mahkamah Konstitusi Nomor 16/PUU-X/2012 Terhadap Kewenangan Penyidikan Kejaksaan Pada Tindak Pidana Korupsi Dalam Prespektif Sistem Peradilan Pidana}

Mahkamah Konstitusi (MK) merupakan salah satu lembaga negara dalam sistem ketatanegaraan Indonesia yang juga merupakan pemegang kekuasaan kehakiman bersama - sama dengan Mahkamah Agung (MA). Mahkamah Konstitusi dibentuk sebagai hasil reformasi yang pembentukannya didasarkan pada Pasal 24 dan Pasal 24C Perubahan Ketiga Undang - Undang Dasar Negara Republik Indonesia Tahun 1945 (UUD NRI 1945) jo. Pasal III Aturan Peralihan Perubahan Keempat UUD NRI 1945.

Merujuk pada ketentuan Pasal 24C Ayat (1) dan (2) UUD NRI 1945, Mahkamah Konstitusi diberi kewenangan dalam melaksanakan kekuasaan kehakiman yang kemudian dijabarkan ke dalam empat kewenangan serta satu kewajiban Mahkamah Konstitusi. Dalam kedua ayat tersebut disebutkan bahwa mahkamah Konstitusi berwenang mengadili pada tingkat pertama dan terakhir yang putusannya bersifat final untuk menguji undang undang terhadap Undang - Undang Dasar, memutus sengketa kewenangan Lembaga Negara yang kewenangannya diberikan oleh Undang - Undang Dasar, memutus pembubaran partai politik, dan memutus perselisihan tentang hasil pemilu.

Mahkamah Konstitusi wajib memberi putusan atas pendapat Dewan Perwakilan Rakyat mengenai dugaan pelanggaran Presiden dan / atau Wakil Presiden menurut Undang - Undang Dasar. Berdasarkan kewenangan yang dimilikinya tersebut, Mahkamah Konstitusi merupakan pengadilan tingkat pertama dan terakhir yang putusannya bersifat final. Artinya, tidak ada upaya hukum lain atas putusan Mahkamah Konstitusi, seperti yang terjadi pada pengadilan lain. Terkait dengan dalil pemohon Bahwa tidak ada pasal dalam UU 31/1999 yang secara tegas menyatakan bahwa Kejaksaan mempunyai kewenangan dalam melakukan penyidikan tindak pidana korupsi. Namun, ada setidaknya 3 pasal dalam UU 31/1999 yang ditafsirkan bahwa Kejaksaan masih mempunyai kewenangan untuk melakukan penyidikan tindak pidana korupsi sebagaimana tercantum dalam Pasal 26, Pasal 27, dan Pasal 39. Pasal 26: "Penyidikan, penuntutan, dan pemeriksaan di sidang pengadilan terhadap tindak pidana korupsi, dilakukan berdasarkan hukum acara pidana yang berlaku, kecuali ditentukan lain dalam UndangUndang ini". Pasal 27: "Dalam hal ditemukan tindak pidana korupsi yang sulit pembuktiannya, maka dapat dibentuk tim gabungan di bawah koordinasi Jaksa Agung". Pasal 39: "Jaksa Agung mengkoordinasikan dan mengendalikan Penyelidikan, penyidikan, dan penuntut tindak pidana korupsi yang dilakukan bersama-sama oleh orang yang tunduk pada Peradilan Umum dan Peradilan Militer".

Bahwa ketentuan Pasal 26 UU 31/1999 tidak memberikan kewenangan penyidikan kepada Kejaksaan, tetapi secara tegas pasal tersebut 
mengakui bahwa KUHAP sebagai hukum acara peradilan tindak pidana korupsi. KUHAP tidak mengakui Kejaksaan sebagai penyidik, tetapi hanya berfungsi sebagai penuntut umum.

Selanjutnya, di dalam Ketentuan Peralihan, Pasal 284 ayat (2) KUHAP menyatakan "Dalam waktu dua tahun setelah undang undang ini diundangkan maka terhadap semua perkara diberlakukan ketentuan Undang 20 Undang ini, dengan pengecualian untuk sementara mengenai ketentuan khusus acara pidana sebagaimana tersebut pada UndangUndang tertentu, sampai ada perubahan dan atau dinyatakan tidak berlaku lagi”.

Penjelasan Pasal 284 ayat (2) KUHAP Yang dimaksud dengan semua perkara adalah perkara yang telah dilimpahkan ke pengadilan. Sedangkan yang dimaksud dengan "ketentuan khusus acara pidana sebagaimana tersebut pada undang-undang tertentu" ialah ketentuan khusus acara pidana sebagaimana tersebut pada Undang-undang tentang pengusutan, penuntutan dan peradilan tindak pidana ekonomi Undang-undang Nomor 7 Drt. Tahun 1955 dan Undang-undang tentang pemberantasan tindak pidana korupsi (Undang-undang Nomor 3 Tahun 1971 dengan catatan bahwa semua ketentuan khusus acara pidana sebagaimana tersebut pada undang-undang tertentu akan ditinjau kembali, diubah atau dicabut dalam waktu yang sesingkat-singkatnya.

Dengan adanya UU 31/1999, maka Undang-Undang Nomor 3 Tahun 1971 dinyatakan tidak berlaku. Pasal 44 UU 31/1999 menyatakan "Pada saat mulai berlakunya Undang-undang ini, maka Undang-undang Nomor 3 Tahun 1971 tentang Pemberantasan Tindak Pidana Korupsi (Lembaran Negara Tahun 1971 Nomor 19, Tambahan Lembaran Negara Nomor 2958), dinyatakan tidak berlaku". Oleh karena itu, ada tidaknya kewenangan kejaksaan dalam penyidikan tindak pidana korupsi sebagaimana diatur dalam Ketentuan Peralihan Pasal 284 ayat (2) KUHAP, tidak lagi menggunakan rujukan UndangUndang Nomor 3 Tahun 1971, melainkan UU 31/1999.

Berdasarkan pada permasalahan tersebutlah maka diajukanlah permohonan pengujian pasal 30 ayat (1) huruf d Undang-Undang Nomor 16 Tahun 2004 Tentang Kejaksaan, Pasal 39 Undang-Undang Nomor 31 Tahun 1999 Tentang Pemberantasan Tindak Pidana Korupsi dan Pasal 44 Ayat (4) dan Ayat (5), Pasal 50 ayat (1), ayat (2), ayat (3) dan ayat (4) UndangUndang Nomor 30 Tahun 2002 Tentang Komisi Pemberantasan Korupsi (KPK).

Bahwa ketentuan tentang kewenangan penyidikan oleh kejaksaan diatur dalam Pasal 30 ayat (1) huruf d UU 16/2004yang menyatakan " $D i$ bidang pidana, kejaksaan mempunyaitugas dan wewenang: d) melakukan penyidikan terhadap tindakpidana tertentu, berdasarkan undang-undang”. DalamPenjelasan Pasal 30 ayat (1) huruf d menyatakan "Kewenangandalam ketentuan ini adalah kewewenangan sebagaimana diaturmisalnya adalah Undang-Undang Nomor 26 Tahun 2000tentang Pengadilan Hak Asasi Manusia dan Undang-UndangNomor 31 Tahun 1999 tentang Pemberantasan TindakanPidana Korupsi sebagaimana telah diubah 
dengan Undang-Undang Nomor 20 Tahun 2001 juncto Undang-Undang Nomor30 Tahun 2002 tentang Komisi Pemberantasan Tindak PidanaKorupsi". Dengan begitu bahwa ketentuan yang ada dalam Pasal 30 ayat (1) huruf d UU16/2004, memberikan kewenangan kepada Kejaksaan untukmelakukan penyidikan tindak pidana tertentu, asalkan di dalamUndang-Undang yang khusus tersebut dinyatakan bahwakejaksaan memiliki kewenangan untuk melakukan penyidikan.

Berdasarkan pada permasalahan tersebutlah maka diajukanlah permohonan pengujian di Mahkamah Konstitusi yakni pasal 30 ayat (1) huruf d Undang-Undang Nomor 16 Tahun 2004 Tentang Kejaksaan, Pasal 39 Undang-Undang Nomor 31 Tahun 1999 Tentang Pemberantasan Tindak Pidana Korupsi dan Pasal 44 Ayat (4) dan Ayat (5), Pasal 50 ayat (1), ayat (1), ayat (3) dan ayat (4) Undang-Undang Nomor 30 Tahun 2002 Tentang Komisi Pemberantasan Korupsi (KPK) terhadap pasal 1 Ayat (3) dan pasal 28D Ayat (1) Undang-Undang Dasar 1945.

Adapun pertimbangan Majeis Hakim dalam putusannya bahwa Pasal 4 ayat (1) UUD 1945 menyatakan, "PresidenRepublik Indonesia memegang kekuasaan pemerintahan menurut Undang-Undang Dasar" dan Pasal 20 ayat (2) UUD 1945 menyatakan, "Setiap rancanganUndang-Undang dibahas oleh Dewan Perwakilan Rakyat dan Presiden untukmendapat persetujuan bersama." Berdasarkan kedua pasal tersebut, makaPresiden selain sebagai pemegang kekuasaan pemerintahan (eksekutif), jugaberfungsi sebagai pembentuk Undang-Undang (legislatif) bersama-sama denganDewan Perwakilan Rakyat. Dengan demikian UUD 1945 tidak melarang fungsiganda tersebut. Dengan pertimbangan tersebut Hakim Mahkamah Konstitusi menolak semua perrmohanan pemohon.

Lebih lanjut penulis perlu mengutip beberapapertimbangan dalam Putusan Mahkamah Nomor28/PUU-V/2007 antara lain mempertimbangkan, "Dengandemikian kewenangan polisi sebagai penyidik tunggal bukan lahir dari UUD 1945tetapi dari Undang-Undang,". Kata "sesuai" dengan hukum acara pidana danperaturan perundang-undangan lainnya memungkinkan alat penegak hukumlainnya seperti kejaksaan diberi wewenang untuk melakukan penyidikan.Sementara itu Pasal 24 ayat (3) UUD 1945 menyatakan, "Badan-badan lain yangfungsinya berkaitan dengan kekuasaan kehakiman diatur dengan undang-undang.UndangUndang yang diturunkan dari amanat Pasal 24 ayat (3) UUD 1945 ituantara lain adalah UU Kejaksaan. Pasal 30 ayat (1) huruf d UU Kejaksaanberbunyi, "Melakukan penyidikan terhadap pidana tertentu berdasarkan undang-undang”.

Mencermati pertimbangan haikim diatas, penulis beranggapan bahwa dengan lahirnya Putusan Mahkamah Konstitusi ini disatu sisi memperkuat kewenangan penyidikan oleh kejaksaan terhadap tindak pidana korupsi.Akan tetapi disisi yang lain kewewenangan ini menimbulkan tumpang tindih kewenangan antar lembaga lembaga peneagak hukum dan peraturan didalamnya.Pembagian kekuasaan penyidikan dan penuntutan yang jelas dan tegas antara kepolisian dan kejaksaan dalam rangka due 
processof law guna mencapai the integrated criminal justice system dalam sistem peradilan pidana di Indonesia sesungguhnya dibutuhkan semata-mata untuk menjamin hak asasi negara. Selain itu. Bahwa KUHAP mengakomodir asas yang melindungi HAM yakni dengan adanya diferensiasi penegakan hukum, denganmembagi menjadi empat yakni penyelidikan, penyidikan, penuntutan, pemeriksaan di pengadilan. Hal ini bertujuan untukmengadakan kontrol satu dengan yang lain. Dengan adanyakontrol tersebut, maka akan melindungi kepastian hukum danHAM bagi tersangka atau terdakwa. Di samping itu, kontroltersebut untuk meningkatkan profesionalitas masing-masingunsur itu supaya lebih efektif tetapi itu masih dalam satubingkai. Polisi dari menyidik pertama kali sudah mengirim SuratPemberitahuan Dimulainya Penyidikan (SPDP) kepada jaksa, artinya bahwa jaksa bisa mengontrol mulai dari penyidikan, selanjutnya jaksa juga bisa mengontrol pada tahap prapenuntutan. Kemudian jaksa mengirimkannya ke pengadilanjuga dan mengirimkan tembusan kepada polisi jadi sudah adasistem kontrol. Sistem diferensiasi penegakan hukum danadanya check and balance antara penyidik dan penuntut umum sebagaimana diatur dalam KUHAP sejalan dengan ketentuanPasal 28D ayat (1) UUD 1945 yang mengamanatkan "Setiaporang berhak atas pengakuan, jaminan, perlindungan, dan kepastian hukum yang adil serta perlakuan yang sama dihadapan hukum";

Selain itu menurut analisa penulis Kejaksaan yaitu dengan kewenangan Penyidikan sekaligus Penuntutan dalam proses hukum pidana sebagaimanabersumber pada ketentuan-ketentuan Undang-Undang yangdiuji dalam perkara a quo, maka dapat dipastikan bahwamekanisme check and balances dalam proses hukum tersebuttelah terabaikan atau dengan kata lain, kewenangan rangkap/ganda yang dimiliki Kejaksaan dimaksud terlaksanatanpa kendali dan tanpa pengawasan horizontalmaupun vertikal, sehingga sangat rentan dan potensial untukterjadinya "kesewenangwenangan (arbitrary) dan ketidakadilanserta ketidakpastian hukum.

\section{Penutup}

\section{Kesimpulan}

a. Tidak adanya aturan norma yang secara tegas yang menyatakan bahwa kejaksaan memliki kewenangan penyidikan terhadap perkara tindak pidana korupsi serta kewenangan penegak hukum terkait perkara tindak pidana korupsi secara normatif telah sesuai dengan sistem peradilan pidana yang termaktub dalam KUHAP yakni Kepolisian sebagai penyidik, Kejaksaan sebagai penuntut umum, pengadilan sebagai yang menjatuhkan vonis dan Lembaga Pemasyarakat sebagai tempat pelaksanaan putusan hakim. Akan tetapi namun secara empiris masih menimbulkan tumpang tindih dalam penyidikan Perkara tindak pidana korupsi antara lembaga kepolisian dan kejaksaan. 
b. Kewenangan jaksa sebagai penyidik sekaligus sebagai penuntut umum tersebut maka peranannya dalam tindak pidana korupsi sangatlah dominan. Hal ini menjadikan kewenangan ganda tersebut rawan diselewengkan atau disalahgunakan karena tidak adanya kontrol dalam menjalankan kedua kewenangan, selain jaksa sebagai penyidik terhadap tindak korupsi, jaksa tetap menjalankan fungsi sebagai penuntut umum.

\section{Saran}

a Guna mempertegas dan menyelesaikan polemik atas legalitas kewenanganjaksa dalam melakukan penyidikan tindak pidana korupsi, maka pembentukundang- undang sebaiknya melakukan pembaruan terhadap Undang undang Nomor 16 Tanun 2004 Tentang Kejaksaan.Pembentuk undang-undang harus menegaskan apakah jaksa berwenang melakukan penyidikan terhadap tindak pidana korupsi atau tidak. Selain itu perlu adanya pemahaman yang sama tentang masing-masing kewenangan antar sub sistem dalam sistem peradilan pidana dalam penegakan hukum pada tindak pidana korupsi, mengingat kejahatan korupsi adalh kejahatan yang bersifat kejahatan luar biasa (ordinary crime). Sehingga dibutuhkan tindakan penegakan hukum yang luar biasa pula mingat penegakan hukum adalah upaya untuk menganggulangi kejahatan yang pada gilirannya memberikan kepuasan kepada masyarakat.

b. Perlu adanya intensitas kontrol dan pengawasan yang tinggi dan kuat baik pengawas intern maupun institusi pengawas eksteren terhahap kinerja kejaksaan dalam penanganan tindak pidana korupsi agar peluang terjadinya kesewenangan bisa di minimilasir sehingga tedapat menciptakan chek and balance.

\section{Daftar Pustaka}

Romli atsasmita, strategi dan kebijakan pemberantasan korupsi pasca konvensi PBB menentang korupsi tahun 2003.

O.C. Kaligis, Pengawasan Terhadap Jaksa Selaku Penyidik Tindak Pidana Khusus dalam Pemberantasan Korupsi, (P.T. Alumni Bandung, 2006) hal 121

C.S.T Kansil, Pengantar Ilmu Hukum dan Tata hokum Indonesia, (Jakarta: BalaiPustaka), 2011, hal. 30

Kadri Husin dan Budi Rizki Husin, Sistem Peradilan Pidana Di Indonesia, (Jakarta: Sinar Grafika), 2016, hal. 7 
Soerjono soekanto, 1986, pengantar penelitian hukum, (Jakarta: UI Press), hal. 124

Ridwan HR, Hukum Administrasi Negara, (Jakarta: Rajawali Pers), 2007, hal. 93

Jimly Asshidiqie, Perkembangan Dan Konsolidasi Lembaga Negara, (Jakarta: sinar Grafika) 2016 hal. 187

Janedjri M. Gaffar, Kedudukan Fungsi dan Peran Mahkamah Konstitusi Dalam Sistem Ketatanegaraan Republik Indonesia, (Surakarta: Jurnal Mahkamah Konstitusi, 2009), Hlm. 1

Taufiqurrohman Syahuri, Tafsir Konstitusi Dari Berbagai Aspek Hukum, (Jakarta: Kencana, 2011), Hal. 111

Jimmly Asshiddiqie, Perihal Undang - Undang di Indonesia, (Jakarta: Sekretariat Jenderal dan Kepaniteraan Mahkamah Konstitusi Republik Indonesia, 2006), Hal. 87

Soedikno Mertokusumo, Hukum Acara Perdata Indonesia, (Yogyakarta: Liberty, 2009), Hal. 175

Marwan Effendy, Kejaksaan Repubik Indonesia, Posisi dan Fungsinya dari Prespektif Hukum, (Jakarta:Ghalia Indonesia), 2007, hal. 127.

Adami Chazawi, Pelajaran HukumPidana Bagian 1, (Jakarta:Raja Grafindo Persada), 2008, hal. 67.

Andi Hamzah, Korupsi di Indonesia Masalah dan Pemecahannya, (Jakarta:PT. Gramedia Pustaka Utama),2001, hal. 7.

Ensiklopedi Hukum Islam, (Jakarta PT. Ikhtiar Baru Van Hoeve), 2003 hal. 974.

Romli Atmasasmita, Sistem Peradilan Pidana (Criminal Justice System) Prespektif Eksistensialisme dan Abolisionalisme, (Jakarta:Penerbit Bina Cipta, Jakarta), 2012, hal. 15.

Muladi, Kapita Selekta Sistem Peradilan Pidana, (Semarang: Badan Penerbit Universitas Diponegoro), 1995 hal. Viii dan 18.

Andi Hamzah, Hukum Acara Pidana Indonesia,(Jakarta: Sinar Grafika), 2010, hal. 12 .

Lilik Mulyadi, Hukum Acara Pidana Indonesia Suatu Tinjauan Khusus Terhadap: Surat Dakwaan, Eksepsi dan Putusan Pengadilan,(Bandung: PT. Citra Aditya Bakti), 2012, hal. 17.

Kelik Pramudya dan Ananto Widianto, Pedoman EtikaProfesi Aparat Hukum, Pustaka Yustisia, Yogyakarta, 2010,hal.. 44

\section{Jurnal/Karya Ilmiah}


Sahuri Lasmadi, tumpang Tindih Kewenangan Penyidikan Pada Tindak Pidana Korupsi Dalam Perspektif Sistem Peradilan Pidana,Jurnal Ilmu Hukum, https://online- journal.unja.ac.id/jimih/article/view/200/177 hal. 3

Sahuri Lasmadi, Analisis Yuridis Kewenangan Kejaksaan Dalam Melakukan Penyidikan Tindak Pidana Korupsi, Jurnal Ilmu Hukum, http://repository.unja.ac.id/597/1/2.\%20Tulisan\%20Sahuri\%20L.pdf, Volume 6 No.2, 2015, hal 12

Martuaful Latifah, Legalitas Kewenangan Jaksa Dalam Penyidikan Tindak Pidana Korupsi, Jurnal Negara Hukum, https://jurnal.dpr.go.id/index.php/hukum/article/view/226/ 167 vol. 3 No. 1, 2012 hal 105

\section{Internet}

Indeks persepsi korupsi 2017, Indonesia peringkat ke-96, http://m.detik.com diakses pada tamggal 11 oktober 2018 pukul 18.50

Kasus korupsi tahun 2017, ICW:kerugian negara Rp6,5triliun” http://nasional.tempo.com. diaksespada tanggal 11 oktober 2018 pada pukul 19.00 .

http://ciputrauceo.net/blog/2016/1/18/arti-kata-implikasidi aksespadatanggal 25 Februari 2019 padapukul 17.00

https://digilib.uns.ac.id/...=/Tinjauan-Yuridis-Tentang-Kewenangan-Bpk-Dan-Bpkpmen hal. 20

https://www.zonareferensi.com/pengertian-korupsidiakses pada tanggal 12 maret 2019 pukul 19.00 . 